\title{
NOTE
}

\section{Relationship of First Hollow Stem and Heading in Winter Wheat}

\author{
Jeffrey T. Edwards,^ Brett F. Carver, and Mark E. Payton
}

\begin{abstract}
The majority of wheat (Triticum aestivum L.) in the southern Great Plains is produced as a dual-purpose crop enterprise. Profitability of the system is highly dependent on removal of cattle (Bos taurus $L$.) from wheat pastures at the first-hollowstem stage of growth. A previous survey implied that earliness of first hollow stem and earliness of heading are independent traits, which would allow a grower to select a cultivar with late first hollow stem without sacrificing early maturity. We evaluated first hollow stem and heading records for 52 hard winter wheat lines $(49 \mathrm{com}-$ mercially available winter wheat cultivars and three advanced experimental lines) during a 7yr period at Stillwater, OK. Our analysis shows a positive, linear relationship between the occurrence of first hollow stem and heading in wheat when these phenological events were expressed as a function of cumulative thermal units after 1 January. When expressed in terms of calendar date, however, intervals between the earliest and latest cultivars for the first-hollow-stem stage were much greater than those for heading date. Overall, our analysis indicates that among commercially available cultivars and advanced experimental lines, choosing a cultivar with later occurrence of first hollow stem will also result in later heading in the same given environment.
\end{abstract}

J.T. Edwards and B.F. Carver, Dep. of Plant and Soil Sciences, Oklahoma State Univ., 368 Agricultural Hall, Stillwater, OK 74078; M.E. Payton, Dep. of Statistics, Oklahoma State Univ., 301 Mathematical Sciences Bldg., Stillwater, OK 74078. Received 30 Jan. 2007. *Corresponding author (jeff.edwards@okstate.edu).

Southern Great Plains agriculture is dominated by the dualPurpose wheat (Triticum aestivum L.) production system (Hossain et al., 2004). In this system, wheat is typically sown in early September, grazed by cattle (Bos taurus L.) from mid-October until early March, and harvested for grain in early June (Krenzer, 1991). While wheat grain yields are frequently lower for dual-purpose wheat than for grain-only production (Edwards et al., 2005), the majority of wheat producers still prefer the dual-purpose system, as it provides a second source of income and spreads risk. Profitability of the system, however, is highly dependent on termination of grazing at the first-hollow-stem stage of wheat growth during late winter (Fieser et al., 2006; Redmon et al., 1996).

The first-hollow-stem stage occurs just after leaf sheaths are strongly erected (Feekes Stage 5; Large, 1954) and has been identified as the optimal wheat growth stage for removal of cattle from wheat pasture to optimize overall profitability of the dual-purpose system (Redmon et al., 1996). Therefore, late first hollow stem is a desirable characteristic for a dual-purpose wheat cultivar, as it allows later grazing in the spring than a cultivar with early first hollow stem.

Krenzer (2000) proposed that late development of first hollow stem is not phenologically associated with later heading or crop maturity. This is important, as hot, dry weather conditions frequently occur during wheat grain fill in the southern Great Plains, and this often results in drought and heat stress. Early-maturing

Published in Crop Sci. 47:2074-2077 (2007).

doi: $10.2135 /$ cropsci2007.01.0057sc

(C) Crop Science Society of America

677 S. Segoe Rd., Madison, WI 53711 USA

All rights reserved. No part of this periodical may be reproduced or transmitted in any form or by any means, electronic or mechanical, including photocopying, recording, or any information storage and retrieval system, without permission in writing from the publisher. Permission for printing and for reprinting the material contained herein has been obtained by the publisher. 
wheat cultivars often have a yield advantage over later maturing cultivars in this environment, as drought and heat stress generally worsen during the grain-fill period. So, if late first hollow stem also resulted in later maturity, then the increased cattle gains associated with a longer grazing duration of late first-hollow-stem cultivars could be offset by decreased grain yield associated with suboptimal environmental conditions during grain fill of these same cultivars. In this study, we examined the relationship between first hollow stem and heading of some commercially available winter wheat cultivars and advanced experimental lines from the southern Great Plains.

\section{MATERIALS AND METHODS}

Data were collected from nonreplicated wheat cultivar plots from 1999 to 2005 at Stillwater, OK $\left(97^{\circ} 05^{\prime} \mathrm{W}, 36^{\circ} 07^{\prime} \mathrm{N}\right)$. Soil type was a Kirkland silt loam (fine, mixed, superactive, thermic Udertic Paleustolls). Plots consisted of eight rows $15 \mathrm{~cm}$ wide by $12 \mathrm{~m}$ long and were sown within $2 \mathrm{~d}$ of 15 September each year, which is the typical planting date for dualpurpose wheat in the region. The seedbed was conventionally prepared and fertilized according to Oklahoma State University soil test recommendations for dual-purpose wheat. All plots were unirrigated and the cultivars evaluated varied by year (Table 1).

First-hollow-stem data were collected at approximate 3-d intervals beginning 15 February each year by removing plants from approximately $0.5 \mathrm{~m}$ of row at random locations in each plot. The 10 largest tillers from each sample were then selected, severed from the roots just above the crown, split longitudinally at the base, and measured for hollow stem (Redmon et al., 1996). The date of the first-hollow-stem stage was recorded when mean hollow stem length of a cultivar had reached $1.5 \mathrm{~cm}$. Heading date was recorded as the date at which $50 \%$ of the heads were fully emerged in the same plots used for first-hollowstem measurements.

Temperature data were collected using an on-site weather station and thermal units were calculated using a base temperature of $0^{\circ} \mathrm{C}$ (Baker et al., 1986). Thermal units until phenological events were calculated by summation of daily thermal units after 1 January. Using the PROC GLM function of SAS Version 9 (SAS Institute, Cary, NC), we tested for homogeneity of variances among years of the experiment by expressing thermal units until heading as a function of thermal units until first hollow
Table 1. Cultivars and advanced experimental lines included in analysis and least squares means for first hollow stem and heading at Stillwater, OK.

\begin{tabular}{|c|c|c|c|c|c|c|c|c|c|c|c|}
\hline \multirow{3}{*}{$\begin{array}{c}\text { Cultivar } \\
\text { or line } \\
\end{array}$} & \multirow{3}{*}{1999} & \multirow{3}{*}{2000} & \multirow{3}{*}{2001} & \multirow{3}{*}{2002} & \multirow{3}{*}{2003} & \multirow{3}{*}{2004} & \multirow{3}{*}{2005} & \multicolumn{4}{|c|}{ Least square means } \\
\hline & & & & & & & & \multicolumn{2}{|c|}{ First hollow stem } & \multicolumn{2}{|c|}{ Heading } \\
\hline & & & & & & & & ${ }^{\circ} \mathrm{C} \mathrm{d} \mathrm{d}^{\dagger}$ & DOY ${ }^{\ddagger}$ & ${ }^{\circ} \mathrm{C} \mathrm{d}$ & DOY \\
\hline 2137 & $x^{\S}$ & $x$ & $x$ & $x$ & $x$ & $x$ & $x$ & 376 & 69 & 928 & 111 \\
\hline 2145 & & & & $x$ & $x$ & $x$ & $x$ & 311 & 65 & 861 & 108 \\
\hline 2158 & $x$ & $x$ & $x$ & $x$ & $x$ & $x$ & & 394 & 72 & 928 & 111 \\
\hline 2174 & $x$ & $x$ & $x$ & $x$ & $x$ & $x$ & $x$ & 409 & 72 & 925 & 111 \\
\hline Above & & & & $x$ & $x$ & & & 318 & 70 & 826 & 109 \\
\hline AP502CL & & & & & $x$ & $x$ & $x$ & 248 & 59 & 782 & 103 \\
\hline Avalanche & & & & & $x$ & $x$ & $x$ & 294 & 64 & 869 & 108 \\
\hline Chisholm & $x$ & $x$ & $x$ & $x$ & $x$ & & & 399 & 72 & 898 & 110 \\
\hline Coronado & $x$ & $x$ & $x$ & $x$ & $x$ & & & 324 & 64 & 871 & 108 \\
\hline Cossack & & & & $x$ & $x$ & $x$ & & 422 & 79 & 920 & 113 \\
\hline Custer & $x$ & $x$ & $x$ & $x$ & $x$ & $x$ & $x$ & 325 & 63 & 879 & 108 \\
\hline Cutter & & & & $x$ & $x$ & $x$ & $x$ & 228 & 56 & 876 & 110 \\
\hline Cisco & & & & & $x$ & & & 345 & 76 & 837 & 112 \\
\hline Deliver & & & & & $x$ & $x$ & $x$ & 305 & 64 & 842 & 108 \\
\hline Dumas & & & $x$ & $x$ & $x$ & & & 350 & 76 & 863 & 111 \\
\hline Enhancer & & & $x$ & $x$ & $x$ & & & 360 & 77 & 848 & 111 \\
\hline Endurance & & & & & $x$ & $x$ & $x$ & 348 & 72 & 849 & 107 \\
\hline Fannin & & & & & & $x$ & $x$ & 253 & 58 & 812 & 102 \\
\hline G1878 & & & $x$ & $x$ & $x$ & & & 367 & 76 & 879 & 112 \\
\hline Guymon & & & & & & $x$ & $x$ & 220 & 50 & 920 & 109 \\
\hline HG-9 & & & $x$ & & & & & 401 & 82 & 925 & 116 \\
\hline Ike & $x$ & $x$ & $x$ & $x$ & & $x$ & $x$ & 428 & 75 & 986 & 113 \\
\hline Intrada & $x$ & $x$ & $x$ & $x$ & $x$ & $x$ & $x$ & 330 & 64 & 904 & 109 \\
\hline Jagalene & & & & $x$ & $x$ & $x$ & $x$ & 290 & 63 & 860 & 108 \\
\hline Jagger & $x$ & $x$ & $x$ & $x$ & $x$ & $x$ & $x$ & 284 & 59 & 851 & 106 \\
\hline Kalvesta & & & $x$ & $x$ & $x$ & & & 381 & 79 & 857 & 111 \\
\hline Lakin & & & $x$ & $x$ & $x$ & $x$ & $x$ & 417 & 78 & 883 & 110 \\
\hline Lockett & $x$ & $x$ & $x$ & $x$ & & & & 404 & 70 & 1016 & 116 \\
\hline Ogallala & $x$ & $x$ & $x$ & $x$ & & & & 341 & 64 & 965 & 112 \\
\hline OK Bullet & & & & & & $x$ & $x$ & 235 & 52 & 866 & 106 \\
\hline OK98697(exp) & & & & $x$ & & & & 453 & 81 & 950 & 114 \\
\hline OK98699(exp) & & & & $x$ & $x$ & & & 401 & 80 & 878 & 112 \\
\hline OK99212(exp) & & & & & & $x$ & $x$ & 283 & 58 & 839 & 105 \\
\hline Onaga & & & $x$ & $x$ & & & & 392 & 78 & 886 & 112 \\
\hline Ok101 & $x$ & $x$ & $x$ & $x$ & $x$ & $x$ & $x$ & 351 & 66 & 841 & 108 \\
\hline Ok102 & & & & $x$ & $x$ & $x$ & $x$ & 424 & 77 & 884 & 110 \\
\hline Okfield & & & & & & $x$ & $x$ & 312 & 62 & 909 & 108 \\
\hline Overley & & & & & & $x$ & $x$ & 185 & 47 & 790 & 100 \\
\hline Platte & & & & & $x$ & $x$ & & 321 & 71 & 934 & 114 \\
\hline Stanton & & & & & & $x$ & $x$ & 330 & 64 & 942 & 110 \\
\hline Sturdy $2 \mathrm{~K}$ & & & & & & & $x$ & 363 & 64 & 889 & 106 \\
\hline TAM 107 & $x$ & $x$ & $x$ & $x$ & & & & 383 & 67 & 911 & 109 \\
\hline TAM 110 & $x$ & $x$ & $x$ & $x$ & $x$ & $x$ & $x$ & 303 & 61 & 849 & 106 \\
\hline TAM 111 & & & & & $x$ & $x$ & $x$ & 306 & 66 & 875 & 109 \\
\hline TAM 202 & $x$ & $x$ & $x$ & & & & & 325 & 61 & 953 & 111 \\
\hline TAM 302 & $x$ & $x$ & $x$ & $x$ & $x$ & $x$ & & 400 & 73 & 951 & 113 \\
\hline Thunderbolt & & $x$ & $x$ & $x$ & $x$ & $x$ & $x$ & 344 & 68 & 916 & 111 \\
\hline Tomahawk & $x$ & & $x$ & & & & & 419 & 74 & 1002 & 114 \\
\hline Tonkawa & $x$ & $x$ & $x$ & & & & & 366 & 65 & 925 & 109 \\
\hline Trego & & $x$ & $x$ & $x$ & $x$ & $x$ & $x$ & 384 & 72 & 909 & 111 \\
\hline Triumph 64 & $x$ & $x$ & $x$ & $x$ & $x$ & $x$ & & 414 & 74 & 939 & 111 \\
\hline Venango & & & $x$ & $x$ & $x$ & & & 375 & 78 & 911 & 115 \\
\hline
\end{tabular}

tThermal units since 1 January.

${ }^{\ddagger} \mathrm{DOY}=$ day of year.

sAn $\mathrm{x}$ indicates that first hollow stem and heading date measurements were recorded for this wheat cultivar that year ${ }^{\mathrm{T}}(\mathrm{exp})=$ advanced experimental line. 
stem, with year as a covariate. The interaction of thermal units until first hollow stem and year was not significant $(P=0.34)$; therefore, data were pooled across years for analysis.

\section{RESULTS AND DISCUSSION}

Unlike previous reports, our data indicate a positive, linear relationship between the first-hollow-stem stage and head-
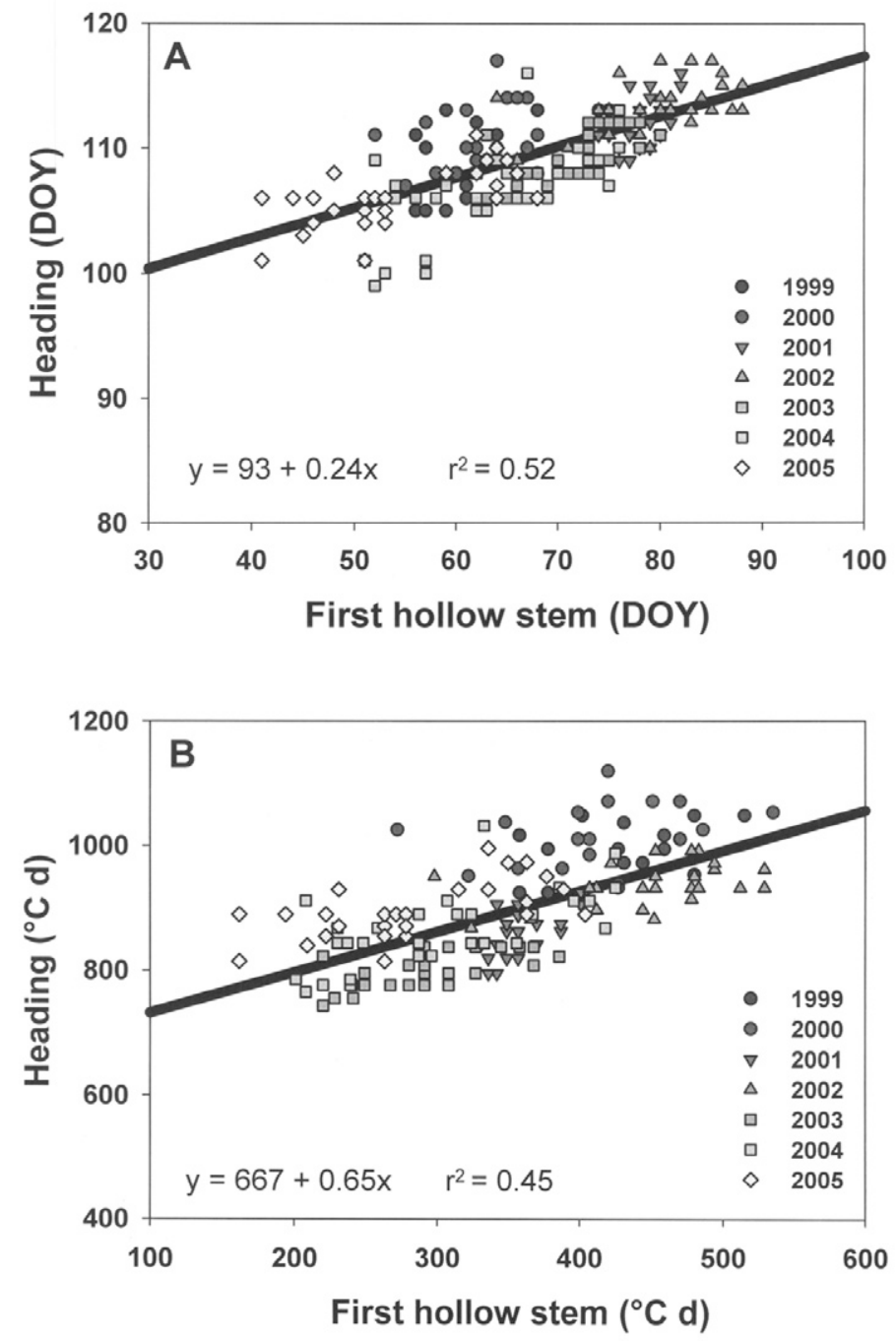

Figure 1. (A) Day of the year (DOY) of wheat heading and (B) thermal time until heading as a function of first hollow stem at Stillwater, OK, 1999 through 2005.

Table 2. Difference between earliest and latest cultivars in thermal time and days until first hollow stem and heading at Stillwater, OK.

\begin{tabular}{|c|c|c|c|c|}
\hline \multirow{2}{*}{ Year } & \multicolumn{2}{|c|}{ First-hollow-stem difference } & \multicolumn{2}{|c|}{ Heading difference } \\
\hline & Thermal time & Occurrence & Thermal time & Occurrence \\
\hline & ${ }^{\circ} \mathrm{C} \mathrm{d}$ & $d$ & ${ }^{\circ} \mathrm{C} \mathrm{d}$ & $d$ \\
\hline 1999 & 157 & 19 & 124 & 8 \\
\hline 2000 & 263 & 22 & 169 & 10 \\
\hline 2001 & 75 & 8 & 130 & 7 \\
\hline 2002 & 231 & 24 & 124 & 8 \\
\hline 2003 & 166 & 17 & 94 & 6 \\
\hline 2004 & 224 & 25 & 266 & 17 \\
\hline 2005 & 242 & 27 & 181 & 10 \\
\hline
\end{tabular}

ing date. This relationship was evident whether phenological events were expressed as calendar dates (Fig. 1A) or as thermal units after 1 January (Fig. 1B). While there was some variation unexplained by the linear models, our data clearly indicate that, among commercially available cultivars and advanced experimental lines, choosing a cultivar with later occurrence of first hollow stem will also result in later heading in the same given environment.

The positive, linear relationship between first hollow stem and heading does not necessarily mean that a wheat producer who selects a cultivar with very late occurrence of first hollow stem will experience a much later harvest than would be associated with an early first-hollow-stem cultivar. Differences in average daily temperatures leading up to first hollow stem and heading, and the associated differences in how rapidly thermal units are accumulated, would compress the differences among cultivars in calendar heading dates more than the differences in calendar dates for first hollow stem. This may explain why previous reports (Krenzer, 2000) have indicated no relationship between the two phenological events. For example, there was a $157^{\circ} \mathrm{C}$ $\mathrm{d}$ difference among genotypes in thermal units until first hollow stem in 1999, which translated to a difference of 19 calendar days among 19 cultivars (Table 2). Likewise there was $124^{\circ} \mathrm{C}$ d difference among genotypes in heading, but this only translated to an eight calendar day difference among heading dates. Similar trends were observed for all years of the experiment, indicating that cooler temperatures before the occurrence of first hollow stem would allow growers to select cultivars with much later first hollow stem and provide an additional 14 to $21 \mathrm{~d}$ of grazing yet delay heading only 7 to $10 \mathrm{~d}$.

Our data emphasize that both environmental and genotypic factors influence the onset of first hollow stem in winter wheat. Differences between the earliest and latest cultivars in thermal units until first hollow stem, for example, ranged from 75 to $242^{\circ} \mathrm{C} \mathrm{d}$ among years of the experiment. This occurred even though planting date, management, and cultivars used were similar among all years. Further research is needed to develop a more mechanistic understanding of how environmental and genotypic factors influence wheat phenology in an early-sown, dual-use scenario.

Our analysis focused on a contemporary genetic pool of commercially released hard red and hard white winter wheat cultivars and three advanced experimental lines. Thus, our genetic sample represents a fixed set of lines with genes selected during cultivar development that confer a relatively narrow window for heading date. In addition, it is possible that genes were inadvertently selected that influenced the first-hollow-stem phenological trait as well. A logical extension of this phenotypic analysis is to 
examine the genotypic relationship between first hollow stem and heading date in a population of random lines produced by random assortment of genes influencing either or both traits. If extensive genetic variation does exist, it would be necessary to evaluate the physiological consequences of a shorter interval between first hollow stem and heading. A short interval, associated with late first hollow stem and early heading date, for example, might be associated with lower total biomass accumulation and lower grain yield.

\section{References}

Baker, J.T., P.J. Pinter, Jr., R.J. Reginato, and E.T. Kanemasu. 1986. Effects of temperature on leaf appearance in spring and winter wheat cultivars. Agron. J. 78:605-613.

Edwards, J., R. Kochenower, R. Austin, B. Carver, and R. Hunger. 2005. Oklahoma wheat variety performance tests. Publ. PT 2005-10. Available at http://www.wheat.okstate.edu/vtr/
grainyield/20042005/PT\%202005-10\%20Oklahoma\%20W heat $\% 20$ Variety\%20Performance\%20Tests.pdf (verified 16 July 2007). Okla. Coop. Ext. Serv., Stillwater.

Fieser, B.G., G.W. Horn, J.T. Edwards, and E.G. Krenzer, Jr. 2006.

Timing of grazing termination in dual-purpose winter wheat enterprises. Prof. Anim. Sci. 22:210-216.

Hossain, I., F.M. Epplin, G.W. Horn, and E.G. Krenzer, Jr. 2004. Wheat production and management practices used by Oklahoma grain and livestock producers. B-818. Okla. Agric. Exp. Stn., Stillwater.

Krenzer, E.G., Jr. 1991. Wheat for pasture. OSU Ext. Facts 2586. Okla. State Univ. Coop. Ext. Serv., Stillwater.

Krenzer, E.G., Jr. 2000. First hollow stem rating for wheat varieties. Prod. Tech. Rep. PT-2000-14. Dep. of Plant and Soil Sci., Okla. State Univ., Stillwater.

Large, E.C. 1954. Growth stages in cereals: Illustrations of the Feekes scale. Plant Pathol. 3:128.

Redmon, L.A., E.G. Krenzer, Jr., D.J. Bernardo, and G.W. Horn. 1996. Effect of wheat morphological stage at grazing termination on economic return. Agron. J. 88:94-97. 